\title{
Synthesis of Protein Hydrolysate from the Prepupae of Hermetia illucens using a Papain Enzymes
}

\author{
${ }^{1,2}$ Rini Triani, ${ }^{1}$ Rika Alfianny, ${ }^{1}$ Robert Manurung and ${ }^{1}$ Muhammad Yusuf Abduh \\ ${ }^{1}$ School of Life Sciences and Technology, Institut Teknologi Bandung, Jalan Ganesha 10, \\ Bandung 40132, Indonesia \\ ${ }^{2}$ Faculty of Engineering Pasundan University, Jalan Dr. Setiabudhhi No. 193, Bandung 40153, Indonesia
}

Correspondence

M.Y. Abduh, School of Life Sciences and Technology, Institut Teknologi Bandung, Jalan Ganesha 10, Bandung 40132, Indonesia, Tel.: +62 22 2511575; +62 22 2534107 Received: April 14, 2020

Accepted: May 8, 2020

Published online: March 25, 2021

\begin{abstract}
The aim of this study was to determine optimum enzyme concentration and hydrolysis time needed to hydrolyze black soldier fly prepupae into a protein hydrolysate. The prepupae were homogenized with aquadest and papain enzyme $\left(0-9 \%\right.$ on a weight basis) at $\mathrm{pH} 7$ for $24-72 \mathrm{~h}$ at $55^{\circ} \mathrm{C}$. At optimum conditions (enzyme concentration of $6 \%$ on a weight basis and hydrolysis time of $24 \mathrm{~h}$ ), the yield of protein hydrolysate was $31 \%$ on a dry weight basis. The protein content increased from 39.7 to $61 \%$ (dry weight basis) whereas the lipid content in the protein hydrolysate decreased from 30.3 to $0.5 \%$ (dry weight basis). Hydrolysis of the prepupae with a papain enzyme increased the amino acid content from 15.4 to $47.1 \%$ on a weight basis. The black soldier fly prepupae contains 15 detectable amino acids primarily consists of glutamic acid $(10.7 \%)$, alanine $(10.7 \%)$, leucine $(10 \%)$ and valine $(9 \%)$. After hydrolysis with a papain enzyme, the composition of the amino acid changed and primarily consists of glutamic acid (17.3\%), tyrosine (9.4\%), leucine $(9.4 \%)$ and alanine $(8.9 \%)$. The protein hydrolysate may find application as a supplement for feed and food for a better absorption of nutrients in animal intestine.
\end{abstract}

Keywords: Amino acid, black soldier fly prepupae, enzymatic hydrolysis, papain, protein hydrolysate

\section{INTRODUCTION}

As the fourth most populated country in the world, Indonesia produces a huge amount of organic waste. The organic waste may causes a huge environmental problem when not handled properly, but may also provides a massive opportunity when biologically converted into valuable bioproducts. Protein is one of the most prominent bioconversion products that can be produced from organic waste by insects. Black soldier fly
(Hermetia illucens) larvae ingest on various organic materials including damp grains, animal wastes, decaying fruits and vegetables and other organic materials, reducing up to $80 \%$ from the original volume (Diener et al., 2015; Sandec, 2017; Mertenat et al., 2019).

Within its growth cycle, Black Soldier Fly Larva (BSFL) will convert organic waste into its own biomass, metabolism and residue (Salomone et al., 2017; Abduh et al., 2018). When compared to other phases in the

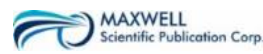

(C) The Author(s) 2020. This article is licensed under a Creative Commons Attribution 4.0 International License, which permits use, sharing, adaptation, distribution and reproduction in any medium or format, as long as you give appropriate credit to the original author(s) and the source, provide a link to the Creative Commons license, and indicate if changes were made. The images or other third-party material in this article are included in the article's Creative Commons license, unless indicated otherwise in a credit line to the material. If material is not included in the article's Creative Commons license and your intended use is not permitted by statutory regulation or exceeds the permitted use, you will need to obtain permission directly from the copyright holder. To view a copy of this license, visit http://creativecommons.org/ licenses/by/4.0/. 
insect growth cycle, the prepupae contain the highest amount of nutrients including protein and lipids. As such is because prepupa is the phase where the larva stop consuming food and start immobilizing itself in a chitinhard cocoon to prepare the metamorph process into a pupa and then a winged body - a fly. Biomass of black soldier fly prepupae is rich with protein (40-50\%) and lipid (25-30\%) (Diener et al., 2009; Nguyen et al., 2015). Black soldier fly prepupae may become a potential alternative source for producing crude insect oil, protein and chitin that may find wide applications in the field of agriculture and biotechnology.

Protein derived products from black soldier fly prepupae when provided as a crude insect protein has a lower value and limited use compared when provided as a hydrolysate. Protein hydrolysate is a product from the breakdown of protein into short chained peptides, nucleotides and L-amino acids. One potential application of protein hydrolysate is peptone used as a growth medium for microorganism and also in biotechnological researchs (Susetyo, 2000; Wijayanti, 2009). Other applications of protein hydrolysate in the food industry are as food and feed protein additive, filler and emulsifier in food products. In addition, clinical applications of protein hydrolysate have also been suggested for phyenilketonuria and liver diasease (Pigott and Tucker, 1990; Schmidl et al., 1994).

One of the main advantages of protein hydrolysate is that it can be easily absorbed in animal intestine (as a feed proportion) compared to the crude form of protein (Hou et al., 2017; Slizyte et al., 2016). The protein hydrolysate has a high proportion of pure protein and free amino acid with also a high protein efficiency ratio that would be beneficial for the growth of cattle and therefore is flexible in its utilization as an additive for animal feed (Li et al., 2016).

Currently, protein hydrolysate which has been widely produced and used, is derived from various types of fish; either whole fish or remnants of fish fillet production (Bernadeta et al., 2012; Nurilmala et al., 2018), soy beans (Witono et al., 2007) and milk (Korhonen, 2009). Protein hydrolysate can be synthesized through a process called hydrolysis, either by enzyme, acid, or alkali. Protein hydrolysate produced by enzyme has a major advantage; more efficient and effective in synthesizing the hydrolysate without causing any damage to its amino acids (Peterson and Johnson, 1978). In addition, enzymatically synthesized hydrolysate has a more clean-cut whole free amino acid (Slizyte et al., 2016) due to specific hydrolysis owing to the nature of enzyme that is target spesifc (Slizyte et al., 2016).

Systematic studies on the synthesis of protein hydrolysate from insects specifically black soldier fly prepupae are still very scarce. Two main challenges recognized in the enzymatic conversion of black soldier fly into protein hydrolysate are to determine the optimum concentration of enzyme and hydrolysis time (Slizyte et al., 2016). Hence, this study aims to determine the optimum concentration of enzyme and hydrolysis time for producing protein hydrolysate followed by characterisation of the synthesized protein hydrolysate.

\section{MATERIALS AND METHODS}

Materials: Black soldier fly prepupae were retrieved from a Black Soldier Fly Cultivation Unit in Margonda Raya (Depok, Indonesia). The prepupae were previously fed with chicken manure and were harvested at the age of three weeks. Upon received, the prepupae were stored at $-20^{\circ} \mathrm{C}$ before further used. Papain enzyme (1.5-10 U/mg) (Sigma-Aldrich, Singapore) was produced from papain latex. Other chemicals used were ethanol (analytical grade) (Emsure ${ }^{\circ}$, Darmstadt, Germany), sodium hydroxide (technical grade) (PT Brataco Chemical, Jakarta, Indonesia) and acetic acid (analytical grade) (Merck KgaA, Darmstadt, Germany).

Synthesis of protein hydrolysate from the prepupae of black soldier fly: Hydrolysis of black soldier fly prepupae was carried out according to the steps shown in Fig. 1 using a papain enzyme with an activity of 1.5-10 $\mathrm{U} / \mathrm{mg}$. Initially, BSF prepupae were rinsed 8-9 times with aquadest water (conductivity: $7 \mu \mathrm{S} / \mathrm{cm}$ ). The wet and clean BSF prepupae were then homogenized using a food Blender-Philips Glass HR2116 350 w (Phillips, Hamburg, Germany) with additional aquadest at a ratio of 1:3 (one part of BSF prepupae mixed with 3 parts of aquadest), for $4 \mathrm{~min}$.

The mixture was then manually stirred with premeasured amount of hydrolytic papain enzyme with a concentration range shown in Table 1 . The $\mathrm{pH}$ was then measured using a $\mathrm{pH}$ meter (SevenCompact, Mettler Toledo, Greifensee, Switzerland) and adjusted to reach pH 7 using $\mathrm{NaOH}$ (PT Brataco, Jakarta, indonesia) $1 \mathrm{M}$ to increase the $\mathrm{pH}$ and acetic acid (Merck, Darmstadt, Germany) $1 \mathrm{M}$ to decrease the $\mathrm{pH}$. Once $\mathrm{pH} 7$ was reached, the mixture was incubated in a waterbath (Double waterbath BW-D, Lab. Companion, Scienceware, New Jersey, United States ) set at $55^{\circ} \mathrm{C}$ for 24-72 $\mathrm{h}$ as shown in Table 1. The hydrolysis was terminated by increasing the incubation temperature to $85^{\circ} \mathrm{C}$ for $20 \mathrm{~min}$. The hydrolyzed sample was centrifuged using a a Labofuge 200 Centrifuge (Heraeus, Hanau, Germany) and the supernatant was concentrated using a rotary evaporator R-215 (Buchi, Flawil, Switzerland) set at $58^{\circ} \mathrm{C}$ for $15 \mathrm{~min}$ until a paste texture was formed for further analysis.

Determination of hydrolysis process with ninhydrin tests: Ninhydrin tests were carried out to compare the resulting amount of free amino acids present in all samples in order to determine the optimum hydrolysis conditions. The test was modified from a nynhydrin test 


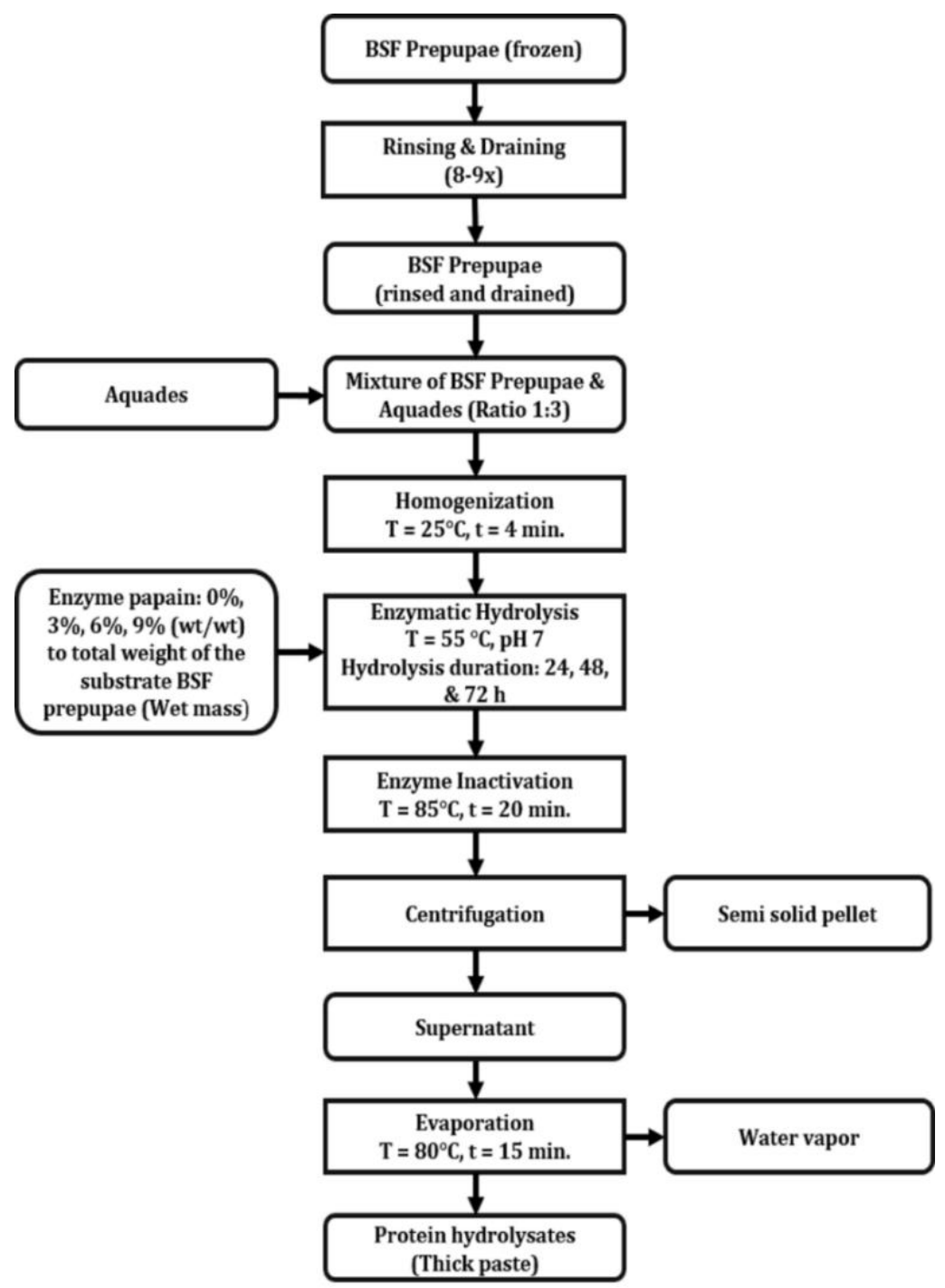

Fig. 1: Schematic diagram for hydrolysis of prepupae from Hermetia illucens using a papain enzyme

$\underline{\text { Table 1: Enzyme concentration and duration of hydolysis }}$ Duration of hydrolysis (h)

\begin{tabular}{llcc}
$\begin{array}{l}\text { Papain enzyme } \\
\text { (\% weight) }\end{array}$ & $24(\%)$ & $48(\%)$ & $72(\%)$ \\
\hline 0 & 0 & 0 & 0 \\
3 & 3 & 3 & 3 \\
6 & 6 & 6 & 6 \\
9 & 9 & 9 & 9 \\
\hline
\end{tabular}

for peptides (Friedman, 2004), where $0.1 \%$ ninhydrin in ethanol (Emsure ${ }^{\circledR}$, Darmstadt, Germany) solution was used as a reactant. The thick paste sample was diluted with aquades with a ratio of $1: 100$. $5 \mathrm{~mL}$ of $0.1 \%$ nynhydrin reagent was mixed with $0.5 \mathrm{~mL}$ aliquot from the diluted sample in a $12 \mathrm{~mL}$ capped glass tube (Iwaki Glass, Indonesia). The mixture was then incubated at $82^{\circ} \mathrm{C}$ in a waterbath (Lab. Companion, Scienceware, New Jersey, United States) for $4 \mathrm{~min}$ to activate the ninhydrin hydrolysis reaction with free amino acids in the sample.

A ninhydrin test showed a positive test for alpha amino acids and proteins that contain free amino acid groups when the yellow ninhydrin changed to a bluepurple color. The color formation from each sample was then measured at a wavelength of $570 \mathrm{~nm}$ using UV1800 spectrophotometer (Shimadzu, Kyoto, Japan). The darker the blue-purple color, the more free amino acid product reacted with ninhydrin, which subsequently gives a higher absorbance/Optical Density (OD) value.

Determination of biomass composition for black soldier fly prepupae: Water content, total crude protein, lipid, ash and fiber content of black soldier fly prepupae were analyzed at Vegetable Research Center (Lembang, Bandung). Total Nitrogen $(\mathrm{N})$ content of the prepupae 
was determined using a Kjehdahl procedure and crude protein was estimated as $\mathrm{N} \times 6.25$ (AOAC, 2005). Total lipid content of the prepupae was determined following a Soxhlet extraction (AOAC, 2012) of dried sample with petroleum ether. Moisture content of the black soldier prepupae was determined by oven drying the sample at $105^{\circ} \mathrm{C}$ until constant weight was obtained. Total ash of the prepupae was determined by removing the organic matter at $500^{\circ} \mathrm{C}$ for $12 \mathrm{~h}$ using crucibles. Determination of total water and ash content were carried out using standard gravimetric methods (AOAC, 2012).

Determination of amino acid profile: Amino acid profiling of the sample was carried out using High Performance Liquid Chromatography (HPLC). The sample was first hydrolyzed with $6 \mathrm{~N} \mathrm{HCL}$ for $22 \mathrm{~h}$ at $110^{\circ} \mathrm{C}$ and followed by a sequence of filtration, derivatization and separation in the HPLC. The analysis was carried out at Comprehensive Chemistry Laboratory, Bogor Agricultural University, Bogor, Indonesia.

Statistical analysis: Experiments were carried out following two-factorial Randomized Complete Design. Reported data was from 2 independent main process replications unless otherwise stated. Analysis of Variance (ANOVA) was performed using SPSS (IBM SPSS Statistics, New York, NY, USA). When experimental factors were found to be significant $(p<0.05)$, differences between means (factor levels) were compared (determined to be significantly different or not) using Tukey's Honest Significant Difference (HSD) test to control for Type I Error.

Determination of yield of protein hydrolysate: The yield of protein hydrolysate was calculated based on the amount of protein hydrolysate produced divided with the amount of black soldier fly prepupae used in the hydrolysis process as shown in Eq. (1):

Yield $(\%)=$ dry mass of hydrolysate $(\mathrm{g}) /$ dry mass of black soldier fly prepupae $(\mathrm{g}) \times 100 \%$

\section{RESULTS AND DISCUSSION}

Biomass composition of black soldier fly prepupae: Biomass composition of black soldier fly prepupae used in this study was analyzed and the results are shown in Table 2. Upon received, the prepupae had a water content of $62.8 \%$. The prepupae used in this study contain $39.7 \%$ crude protein, $30.3 \%$ lipid and $14.7 \%$ ash on a dry mass basis (Table 2). The protein content of black soldier fly prepupae determined in this study lies within range of 39.2-55.2\% reported in previous studies (Caligiani et al., 2018; Liu et al., 2017; Müller et al.,
Table 2: Biomass composition of black soldier fly prepupa and protein hydrolysate

\begin{tabular}{lll}
\hline & Composition (\%) & \\
& ------------------------ \\
Parameter & Prepupa & Hydrolysate \\
\hline Protein $^{\mathrm{a}}$ & 39.7 & 61 \\
Lipid $^{\mathrm{b}}$ & 30.3 & 0.5 \\
Ash $^{\mathrm{c}}$ & 14.7 & 12.8 \\
Starch $^{\mathrm{d}}$ & 1.1 & 0.7 \\
Fiber $^{\mathrm{e}}$ & 7.4 & - \\
Non-N extract $^{\mathrm{f}}$ & 6.8 & 25 \\
\hline
\end{tabular}

a: Kjeldahl method; ${ }^{\text {b: }}$ Soxhlet extraction; ${ }^{\text {c: }}$ Crucible weight; ${ }^{\text {a: }}$ Luff reduction; ${ }^{\mathrm{e}}$ : Mendell method; ${ }^{\mathrm{f}}$ : By difference; Non-N extracts: Soluble $\&$ easily digestible carbs (mono-, di-, polysaccharides)

2017; Spranghers et al., 2016; Abduh et al., 2018). The lipid content of black soldier fly prepupae used in this study also lies in the range of $18.9-35 \%$ reported in previous studies (Abduh et al., 2017; Firmansyah and Abduh, 2019; Zheng et al., 2012).

Effect of enzyme concentration and hydrolysis time: Experiments were carried out to determine the effect of enzyme contentration and hydrolysis time on the hydrolysis of black soldier fly prepupae and the results are shown in Fig. 2. Control samples containing no enzyme ( $0 \%$ weight basis) shows a significantly lower optical density in comparison to other samples containing papain enzyme concentration within all duration of hydrolysis (Fig. 2). The results in Fig. 2 also shows that within the same $24 \mathrm{~h}$ duration of hydrolysis, optical density from samples with a papain concentration of 3\% (weight basis) was significantly lower $(p<0.05)$ than that of 6 and $9 \%$ (weight basis). The duration of 48 $\mathrm{h}$ differs with the latter; although the $3 \%$ (weight basis) papain concentration does not differ from the $3 \%$ papain concentration with $24 \mathrm{~h}$ of hydrolysis. As such shows a similarity with the optical density for samples containing 6 and $9 \%$ papain concentration $(\mathrm{p}<0.05)$.

Samples that were hydrolyzed for $72 \mathrm{~h}$ show no significant difference $(p<0.05)$ in terms of optical density for papain concentration of 6 and $9 \%$. Hydrolysis conditions such as temperature, $\mathrm{pH}$ and water to substrate ratio that may affect the performance of papain in hydrolyzing the samples were set constant for all the samples. Hence, it can be inferred that most probably the papain concentration has reached a critical point where further increase in papain concentration did not facilitate the hydrolysis process.

The overall results indicate that the optimum enzyme concentration and time and for hydrolyzing black soldier fly prepupae are $6 \%$ papain and $24 \mathrm{~h}$ of hydrolysis. In comparison with the results of $72 \mathrm{~h}$, the result was higher than $24 \mathrm{~h}$, especially that of $9 \%$, but statistically they showed no significant difference $(p<0.05)$. Due to the similar outcome $(p<0.05)$, the usage of lower concentration of enzyme particularly $6 \%$, is as effective as $9 \%$ in producing free amino acids. The shorter hydrolysis duration viz. $24 \mathrm{~h}$, also works as affective as the longer ones viz. 48 and $72 \mathrm{~h}$, giving 


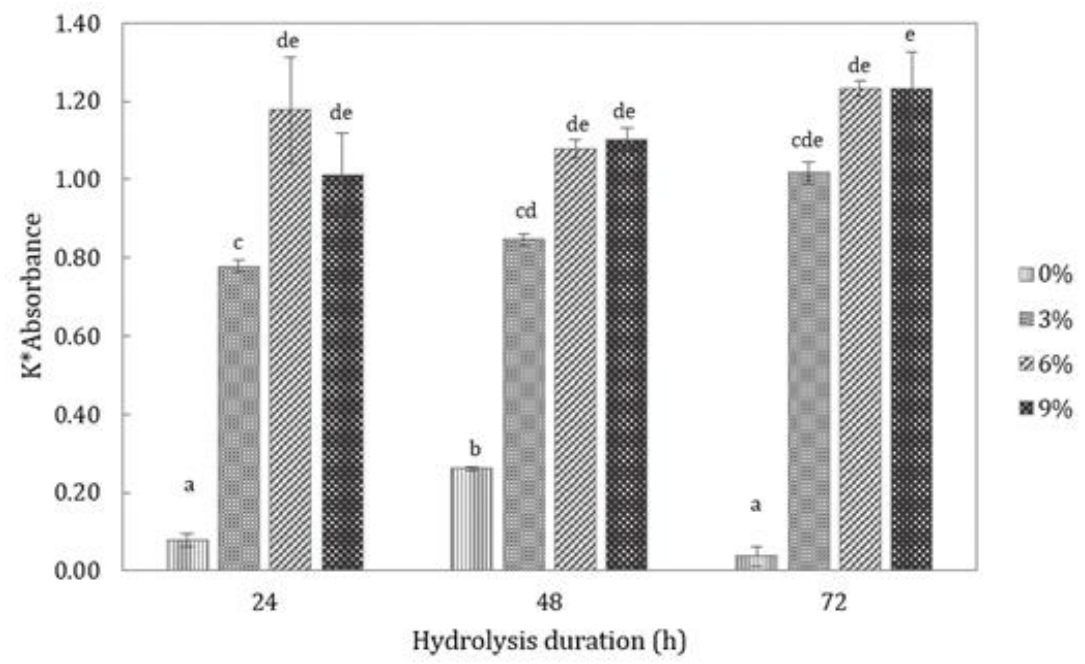

Fig. 2: Spectroscopic optical density at $\lambda 570 \mathrm{~nm}(\mathrm{OD} \lambda 570 \mathrm{~nm})$ quantitating positive ninhydrin test (y-axis) for representing the values of free amino acids for different enzyme concentration and duration of hydrolysis

Standard error values are shown as bars instead of numbers; a-e: Values above the bars with different letters indicate significant differences $(\mathrm{p}<0.05)$

similar Optical Density (OD) ( $<0.05)$ (Fig. 2). Hence, $6 \%$ enzyme concentration and $24 \mathrm{~h}$ of hydrolysis were chosen to be the optimum conditions for the subsequent production of protein hydrolysate from BSF prepupae. Similar study on Mas Ngur seashell (Atactodea striata) reported that the optimum conditions were $6 \%$ papain enzyme concentration for $48 \mathrm{~h}$ to produce the seashell hydrolysate (Purbasari, 2008).

Synthesis of protein hydrolysate at optimum conditions: Synthesis of protein hydrolysate was carried out at the optimum conditions that had been determined earlier $\left(24 \mathrm{~h}, 6 \%\right.$ papain, $\left.55^{\circ} \mathrm{C}, \mathrm{pH} 7\right)$. The hydrolysis of black soldier fly prepupae produced a thick paste with a dark brown color and its composition is shown in Table 2. As much as $666 \mathrm{~g}$ sample of black soldier fly prepupae with a water content of $62.8 \%$ was used to produce 110 $\mathrm{g}$ of protein hydrolysate containing $29.6 \%$ of water. The yield of protein hydrolysate as calculated using Eq. (1) is $31.2 \%$ on a dry weight basis. As such resembles the reported protein hydrolysate yield of $31.58 \%$ using similar hydrolysis method on Atactodea striata (Purbasari, 2008).

From Table 2, it can be observed that the synthesized protein hydrolysate contains $61 \%$ crude protein, $0.5 \%$ lipid and $12.8 \%$ ash on a dry mass basis. Protein content of the hydrolysate synthesized in this study lies in the range of $50-70 \%$ for hydrolysis of black soldier fly using protease enzyme from Bacillus licheniformis (Caligiani et al., 2018). These values are higher than the protein content of hydrolysate produced from fish using a papain enzyme as reported by Hale (1974). The lipid content decreased from 30.3 to $0.5 \%$ (Table 2) after the hydrolysis of black soldier fly prepupae. Reduction of lipid up to $98.3 \%$ indicates a high-quality hydrolysate since a relatively high lipid content will accelerate the end of product shelf-life due to its high susceptibility to lipid oxidation (Boatright and Hettiarachchy, 1995).

Starch content slightly decreased after the hydrolysis. This can be due to the transformation part of the starch into more soluble components after a long heat incubation time (BeMiller and Whistler, 2009). The magnitude of this transformation depends on the water content during heat treatment as well as type of the starch (Hoover and Vasanthan, 1994). Increased starch solubility may help with the digestion of other nutrients in the stomach and gut of animals with the protein.

The non-nitrogen extract (derived by difference) which presumably is soluble and easily digestible carbohydrates (Nowak et al., 2016) could bring a benefit to the diet of the animal livestock. These nutrients can be directly utilized by the animal and thus a good source of energy for growth and metabolism (Garnsworthy and Wiseman, 2012). A higher amount of this extract in the protein hydrolysate also marked a good quality of the hydrolysate product, especially for animal feed application.

Composition of amino acid in the prepupae and protein hydrolysate from black soldier fly: The composition of amino acid in both black soldier fly prepupae and protein hydrolysate also being analyzed using a HPLC and compared with the literature as shown in Table 3. The black soldier fly prepupae contain 15 detectable amino acids primarily consists of glutamic acid $(10.7 \%)$, alanine $(10.7 \%)$, leucine $(10 \%)$ and valine $(9 \%)$. Glutamic acid was reported as the dominant amino 
Table 3: Composition of amino acid black in the biomass and protein hydrolysate from black sloldier fly Composition (\%)

\begin{tabular}{llll} 
& & & Protein hydrolysate (Firmansyah \\
Amino acid & BSF prepupa (this study) & Protein hydrolysate (this study) & 9.7 \\
Aspartic acid & 9.1 & 5.2 & 18.1 \\
Glutamic acid & 10.7 & 17.3 & 4.5 \\
Serine & 4.1 & 2.0 & 2.7 \\
Histidine & 2.6 & 2.8 & 6.1 \\
Glycine & 8.5 & 8.3 & 5.0 \\
Threonine & 3.6 & 3.0 & 3.3 \\
Arginine & 4.8 & 1.3 & 12.1 \\
Alanine & 10.7 & 8.9 & 4.3 \\
Tyrosine & 5.3 & 9.4 & 1.7 \\
Methionine & 1.8 & 3.1 & 7.3 \\
Valine & 9.0 & 8.2 & 4.2 \\
Phenylalanine & 5.8 & 8.2 & 5.3 \\
Isoleucine & 7.0 & 7.2 & 7.7 \\
Leucine & 10.0 & 9.4 & 8.0 \\
Lysine & 7.0 & 5.6 & \\
\hline
\end{tabular}

acid in black soldier fly larvae (Janssen et al., 2017; Müller et al., 2017) and black soldier fly prepupae (Firmansyah and Abduh, 2019; Surendra et al., 2016).

After hydrolysis with a papain enzyme, the composition of the amino acid changed and primarily consists of glutamic acid (17.3\%), tyrosine (9.4\%), leucine $(9.4 \%)$ and alanine $(8.9 \%)$. In another study by Firmansyah and Abduh (2019) on enzymatic hydrolysis of black soldier larvae using a bromelain enzyme, the most dominant amino acids were glutamic acid (18.1\%), alanine (12.1\%), aspartic acid (9.7\%) and lysine (8\%). The presence of hydrophobic amino acid (such alanine, leucine) in the protein hydrolysate can be a sign of the ability of the hydrolysate to scavenge or inhibit free radicals (Saadi et al., 2014). More content of amino acids in the diet of livestock also provides a faster and better absorption of the nutrient in the guts of the animal (Hou et al., 2017).

\section{CONCLUSION}

Protein hydrolysate from black soldier fly prepupae that initially contains $39.7 \%$ protein had been successfully synthesized using a papain enzyme. The optimum conditions for the hydrolysis process occurred at $6 \%$ concentration of papain and hydrolysis time of 24 $\mathrm{h}$ (at $55^{\circ} \mathrm{C}$ and $\mathrm{pH} 7$ ) as indicated by a ninhydrin test (absorbance value of 1.18 at a wavelength of $570 \mathrm{~nm}$ ). The protein hydrolysate had a yield of $31.7 \%$ containing $61 \%$ protein. After hydrolysis with a papain enzyme, the composition of the amino acid changed and primarily consists of glutamic acid, tyrosine, leucine and alanine $(8.9 \%)$. The protein hydrolysate may find application in the field of feed and food industry.

\section{ACKNOWLEDGMENT}

The work described in this study was funded by a research grant from Institut Teknologi Bandung (P3MI KK-ATB 2017).

\section{CONFLICT OF INTEREST}

Authors declare no conflict of interest.

\section{REFERENCES}

Abduh, M.Y., M. Jamilah, P. Istiandari, Syaripudin and R. Manurung, 2017. Bioconversion of rubber seeds to produce protein and oil-rich biomass using black soldier fly larva assisted by microbes. J. Entomol. Zool. Stud., 5(4): 591-597.

Abduh, M.Y., M.H. Nadia, Syaripudin, R. Manurung and R.E. Putra, 2018. Factors affecting the bioconversion of Philippine tung seed by black soldier fly larvae for the production of protein and oil-rich biomass. J. Asia-Pacific Entomol., 21(3): 836-842.

AOAC, 2005. Analysis of Protein. Association of Official Analytic Chemists, Washington, DC.

AOAC, 2012. Official Methods of Analysis. Association of Official Analytic Chemists, Washington, DC.

BeMiller, J. and R. Whistler, 2009. Starch: Chemistry and Technology. 3rd Edn., Academic Press, Oxford.

Bernadeta, P. Ardiningsih and I.H. Silalahi, 2012. Penentuan kondisi optimum hidrolisat protein dari limbah ikan ekor kuning (Caesio cuning) berdasarkan karakteristik organoleptik. J. Kimia Khatulistiwa, 1(1): 26-30.

Boatright, W.L. and N.S. Hettiarachchy, 1995. Effect of lipids on soy protein isolate solubility. J. Am. Oil Chem. Soc., 72(12): 1439-1444.

Caligiani, A., A. Marseglia, G. Leni, S. Baldassarre, L. Maistrello, A. Dossena and S. Sforza, 2018. Composition of black soldier fly prepupae and systematic approaches for extraction and fractionation of proteins, lipids and chitin. Food Res. Int., 105: 812-820. 
Diener, S., C. Zurbrügg and K. Tockner, 2009. Conversion of organic material by black soldier fly larvae: Establishing optimal feeding rates. Waste Manage. Res., 27(6): 603-610.

Diener, S., C.H. Lalander, C. Zurbrügg and B. Vinnerås, 2015. Opportunities and constraints for medium-scale organic waste treatment with fly larvae composting. Proceeding of 15th International Waste Management and Landfill Symposium. Sardinia.

Firmansyah, M. and M.Y. Abduh, 2019. Production of protein hydrolysate containing antioxidant activity from Hermetia illucens. Heliyon 5: e02005.

Friedman, M., 2004. Applications of the ninhydrin reaction for analysis of amino acids, peptides, and proteins to agricultural and biomedical sciences. J. Agr. Food Chem., 52: 385-406.

Garnsworthy, P.C. and J. Wiseman, 2012. Recent Advances in Animal Nutrition. Nottingham University Press, Nottingham.

Hale, M.B., 1974. Using enzymes to make fish protein concentrates. Mar. Fish. Rev., 36(2): 15-18.

Hoover, R. and T. Vasanthan, 1994. Effect of heatmoisture treatment on the structure and physicochemical properties of cereal, legume, and tuber starches. Carbohyd. Res., 252: 33-53.

Hou, Y., Z. Wu, Z. Dai, G. Wang and G. Wu, 2017. Protein hydrolysates in animal nutrition: Industrial production, bioactive peptides, and functional significance. J. Anim. Sci. Biotechnol., 8(1): 24.

Janssen, R.H., J.P. Vincken, L.A.M. van den Broek, V. Fogliano and C.M.M. Lakemond, 2017. Nitrogen-to-protein conversion factors for three edible insects: Tenebrio molitor, alphitobius diaperinus, and hermetia illucens. J. Agr. Food Chem., 65: 2275-2278.

Korhonen, H., 2009. Milk-derived bioactive peptides: From science to applications. J. Funct. Foods, 1(2): 177-187.

Li, S., H. Ji, B. Zhang, J. Tian, J. Zhou and H. Yu, 2016. Influence of black soldier fly (Hermetia illucens) larvae oil on growth performance, body composition, tissue fatty acid composition and lipid deposition in juvenile Jian carp (Cyprinus carpio var. Jian). Aquaculture, 465: 43-52.

Liu, X., X. Chen, H. Wang, Q. Yang, K. Rehman, W. Li, M. Cai, Q. Li, L. Mazza, J. Zhang, Z. Yu and L. Zheng, 2017. Dynamic changes of nutrient composition throughout the entire life cycle of black soldier fly. PLoS One, 12(8): 1-21.

Mertenat, A., S. Diener and C. Zurbrügg, 2019. Black soldier fly biowaste treatment - assessment of global warming potential. Waste Manage., 84: 173-181.
Müller, A., D. Wolf and H.O. Gutzeit, 2017. The black soldier fly, Hermetia illucens - a promising source for sustainable production of proteins, lipids and bioactive substances. Z. Naturforsch. C, 72: 351-363.

Nguyen, T.T.X., J.K. Tomberlin and S. Vanlaerhoven, 2015. Ability of black soldier fly (Diptera: Stratiomyidae) larvae to recycle food waste. Environ. Entomol., 44(2): 406-410.

Nowak, V., D. Persijn, D. Rittenschober and U.R. Charrondiere, 2016. Review of food composition data for edible insects. Food Chem., 193: 39-46.

Nurilmala, M., T. Nurhayati and R. Roskananda, 2018. Limbah industri filet ikan patin untuk hidrolisat protein. J. Pengolahan Hasil Perikanan Indonesia, 21: 287-294.

Peterson, M.S. and A.H. Johnson, 1978. Encyclopedia of Food Science. The AVI Publishing Co., Inc., Westport.

Pigott, G.M. and B.W. Tucker, 1990. Seafood: Effects of Technology on Nutrition. Marcel Dekker, Inc., New York and Basel, pp: 362.

Purbasari, D., 2008. Produksi dan Karakterisasi Hidrolisat Protein dari kerang Mas Ngur (Atactodea striata). Undergradute Thsis, Institut Pertanian Bogor, Bogor.

Saadi, S., N. Saari, F. Anwar, A.A. Hamid and H. Mohd Ghazali, 2014. Recent advances in food biopeptides: Production, biological functionalities and therapeutic applications. Biotechnol. Adv., 33(1): 80-116.

Salomone, R., G. Saija, G. Mondello, A. Giannetto, S. Fasulo and D. Savastano, 2017. Environmental impact of food waste bioconversion by insects: Application of life cycle assessment to process using Hermetia illucens. J. Clean. Prod., 140: 890-905.

Sandec, 2017. Black Soldier Fly Biowaste Processing. 1st Edn., Swiss Federal Institute of Aquatic Science and Technology, Switzerland.

Schmidl, M.K., S.L. Taylor and J.A. Nordlee, 1994. Use of hydrolysate-based products in special medical diets. Food Technol., 48(10): 77-85.

Slizyte, R., K. Rommi, R. Mozuraityte, P. Eck, K. Five and T. Rustad, 2016. Bioactivities of fish protein hydrolysates from defatted salmon backbones. Biotechnol. Rep., 11: 99-109.

Spranghers, T., M. Ottoboni, C. Klootwijk, A. Ovyn, S. Deboosere, B. De Meulenaer, J. Michiels, M. Eeckhout, P. De Clereq and S. De Smet, 2016. Nutritional composition of black soldier fly (Hermetia illucens) prepupae reared on different organic waste substrates. J. Sci. Food Agric., 97(8): 2594-2600. 
Surendra, K.C., R. Olivier, J.K. Tomberlin, R. Jha and S.K. Khanal, 2016. Bioconversion of organic wastes into biodiesel and animal feed via insect farming. Renew. Energ., 98: 197-202.

Susetyo, A.R., 2000. Isolasi pepton secara ekstraksi enzimatis menggunakan limbah perikanan. Undergradute Thsis, Institut Pertanian Bogor, Bogor.

Wijayanti, A.T., 2009. Kajian Penyaringan Dan Lama Penyimpanan Dalam Pembuatan Fish Peptone Dari Ikan Selar Kuning (Caranx leptolepis). Institut Pertanian Bogor. Undergradute Thsis, Institut Pertanian Bogor, Bogor.
Witono, Y., Aulanni'am, A. Subagio and S.B. Widjanarko, 2007. Karakterisasi Hidrolisat Protein kedelai hasil hidrolisis menggunakan protease dari tanaman biduri (Calotropis gigantea). Berk. Penel. Hayati, 13: 7-13.

Zheng, L., Y. Hou, W. Li, S. Yang, Q. Li and Z. Yu, 2012. Biodiesel production from rice straw and restaurant waste employing black soldier fly assisted by microbes. Energy, 47(1): 225-229. 